J. Perinat. Med. 17 (1989) 41

\title{
The somatic growth of a regional birth cohort of 351 preterm infants during the first two years of life
}

\author{
Paula Piekkala', Pentti Kero², Matti Sillanpää1, and Risto Erkkola ${ }^{3}$ \\ ${ }^{1}$ Department of Public Health, ${ }^{2}$ Department of Paediatrics, and ${ }^{3}$ Department of \\ Obstetrics and Gynaecology, University of Turku, Turku, Finland
}

\section{Introduction}

The outcome of infants with low birth weight or short gestation has been of great interest in paediatric research. The growth of such infants has received less attention than the neurodevelopmental outcome. Most studies have been reports on selected patients of large perinatal units rather than population studies. The study patients have mostly been selected according to birth weight rather than gestational age. The purpose of the present study is to investigate whether and how the somatic growth of a regional birth cohort of unselected preterm infants differs from that of their term peers with uncomplicated course of pregnancy, labour, delivery and neonatal period.

\section{Study population and methods}

All infants born in the region of the University Central Hospital of Turku (UCHT) in 1. 6.1981 31. 5. 1982, whose parents were permanently resident in the region of UCHT, were enrolled into the follow-up study. UCHT serves a population of about 460000 people. About 5500 births are annually given in the region of UCHT: half of the deliveries take place at UCHT and another half at eight community hospitals with $200-900$ annual deliveries. The high-risk mothers are selected to deliver at UCHT, but the university maternity unit serves some unselected mothers as well. The only tertiary neonatal unit is located at UCHT. Maternity clinics at the primary level take care of the mothers-to-be with 13 visits on average per pregnancy and a complicance of 99 per cent [10].

\section{Curriculum vitae}

Paula Piekkala, M.D., was born in Joensuu, Finland in 1951 and graduated in 1976 from the Medical Faculty of University of Turku. Resident at the Department of Pediatrics, University Central Hospital of Turku in 1978-81. From the beginning of 1982 she has been assistant and assistant professor in the

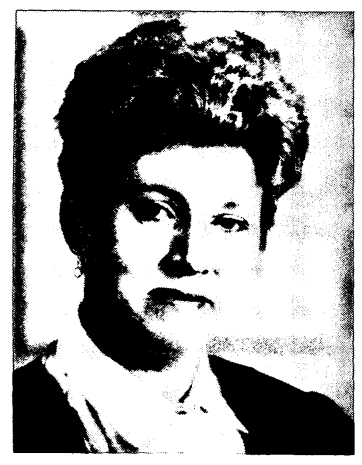
Department of Public Health, University of Turku. Certified paediatrician since 1986. She is particularly interested in perinatal epidemiology and follow-up studies of high-risk children.

The gestational ages of the newborns were assessed according to the last menstrual period of the mother, prenatal ultrasound screenings when available and a scoring system presented by Parkin et al. [12]. If there was discrepancy between the gestational ages defined by these methods the Dubowitz [4] method was applied. The clinical assessment of gestational age was done by paediatricians who examined the newborns at least twice during their stay at the nursery. Newborn infants with gestational ages of less than 37 completed weeks were defined as preterm. The infants with birth weights below the 10th percentile in a fetal growth chart based on the present material accomplished with regional material from the last five years were defined as small-for-gestational age 
(SGA) and the rest as appropriate-for-gestational age (AGA). The reason for not using some of the internationally acknowledged intrauterine growth charts was the fact that newborn babies in southwestern Finland with a mean birth weight of 3520 $\pm 559 \mathrm{~g}$ are heavier for gestational age than these growth charts indicate [13].

Apgar scores were recorded at one, five and fifteen minutes of life. The diagnosis and management of respiratory distress syndrome (RDS) was based on generally accepted principles $[15,16]$.

A total of 351 infants were born before 37 completed weeks of gestation. Eighteen of them died before the age of two years. Eight infants could not be traced for the follow-up. The pre-term infants were divided into subgroups according to gestational age $(33-36$ weeks, $<33$ weeks), birth weight ( $\geq 2000$ grams, $<2000$ grams), the relation of the birth weight to the gestational age (AGA, SGA) and the severity of RDS (none or mild, moderate or severe). Term AGA infants with an uncomplicated course of pregnancy, labour, delivery and neonatal period were selected from the rest of the cohort to serve as the control group. The numbers of the infants who survived in the different groups and the medians with the 10th and 90th percentiles of birth weights, heights and head circumferences and shown in table I.
The follow-up examinations with measurements of weight, height, head and thorax circumferences occurred at the well-baby clinics run by public health nurses and health centre physicians at three, six, eighteen and twenty-four months of conceptional age. The measurements were done in a standardized manner and the data were gathered on forms distributed in advance for the well-baby clinics.

The Kruskal-Wallis test and Mann-Whitney test with Bonferroni correction were applied in the comparisons between the measures obtained in the different groups. The BMDP statistical software was used in the analyses [5].

\section{Results}

The growth curves in weight, height and head circumferences of the preterm infants with gestational ages of $33-36$ weeks and $<33$ weeks as well as the control infants are presented in figures $1-3$. The numerical values of the respective twoyear measures are displayed in Table II. Between the preterm groups there were no significant differences in any measure even if there was a difference of $600 \mathrm{~g}$ between the weight medians of the preterm groups.

Table I. The median weights $(\mathrm{g})$ heights $(\mathrm{cm})$ and heas circumferences $(\mathrm{cm})$ with the 10th and 90th percentiles of the preterm and the control infants at birth

\begin{tabular}{|c|c|c|c|c|c|c|c|c|c|}
\hline \multirow[t]{2}{*}{ Measure } & \multicolumn{2}{|c|}{ Gest. age (w) } & \multirow[b]{2}{*}{$\begin{array}{l}\text { AGA } \\
\mathbf{n}=305\end{array}$} & \multirow[b]{2}{*}{$\begin{array}{l}\text { SGA } \\
n=28\end{array}$} & \multicolumn{2}{|l|}{ BW (g) } & \multicolumn{2}{|l|}{$\underline{R D S}$} & \multirow{2}{*}{$\begin{array}{l}\text { Control } \\
\mathrm{n}=3365\end{array}$} \\
\hline & $\begin{array}{l}33-36 \\
n=288\end{array}$ & $\begin{array}{l}<33 \\
\mathrm{n}=45\end{array}$ & & & $\begin{array}{l}\geq 2000 \\
n=281\end{array}$ & $\begin{array}{l}<2000 \\
\mathrm{n}=52\end{array}$ & $\begin{array}{l}0 \text { or } 1 \\
n=302\end{array}$ & $\begin{array}{l}2 \text { or } 3 \\
n=31\end{array}$ & \\
\hline \multicolumn{10}{|l|}{ Weight } \\
\hline Median & 2710 & 1740 & 2690 & 1955 & 2735 & 1690 & 2660 & 2290 & 3640 \\
\hline 10th & 2110 & 1210 & 1900 & 1360 & 2200 & 1240 & 1900 & 1210 & 3180 \\
\hline 90th & 3280 & 2200 & 3280 & 2230 & 3300 & 1940 & 3270 & 2880 & 4200 \\
\hline \multicolumn{10}{|l|}{ Height } \\
\hline Median, & 47.0 & 42.0 & 47.0 & 44.0 & 48.0 & 42.0 & 47.0 & 45.0 & 51.0 \\
\hline 10th & 44.0 & 38.0 & 43.0 & 39.0 & 45.0 & 38.0 & 43.0 & 38.0 & 48.0 \\
\hline 90th & 50.0 & 46.0 & 50.0 & 46.0 & 50.0 & 45.0 & 50.0 & 49.0 & 53.0 \\
\hline \multirow{2}{*}{\multicolumn{10}{|c|}{$\begin{array}{l}\text { Head } \\
\text { Circumf. }\end{array}$}} \\
\hline & & & & & & & & & \\
\hline Median & 33.5 & 29.0 & 33.0 & 31.0 & 34.0 & 30.0 & 33.0 & 32.0 & 35.0 \\
\hline 10th & 31.0 & 26.0 & 30.0 & 27.0 & 31.0 & 26.0 & 30.0 & 26.0 & 34.0 \\
\hline 90th & 35.0 & 32.0 & 35.0 & 33.0 & 35.0 & 32.0 & 35.0 & 34.0 & 37.0 \\
\hline
\end{tabular}




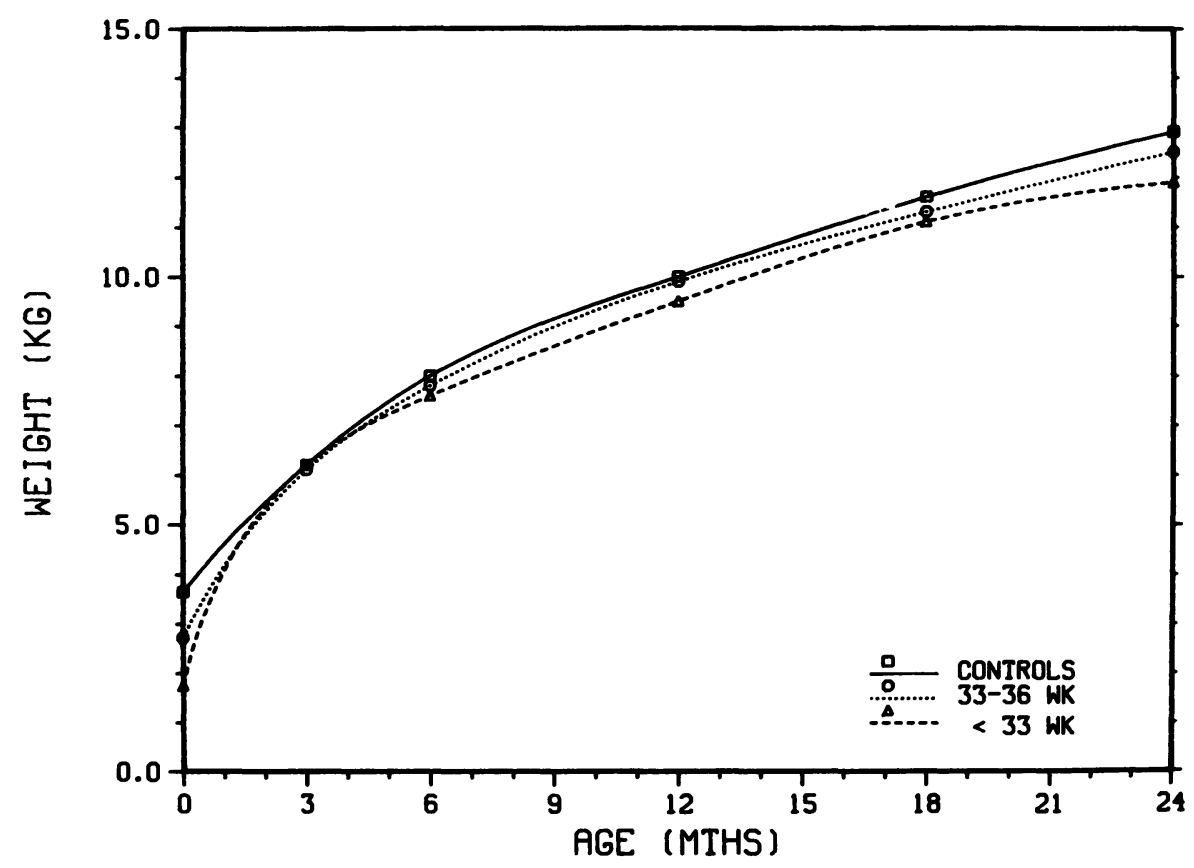

Figure 1. The median weight curves of the preterm infants with $33-36$ and $<33$ weeks gestational age and the control infants.

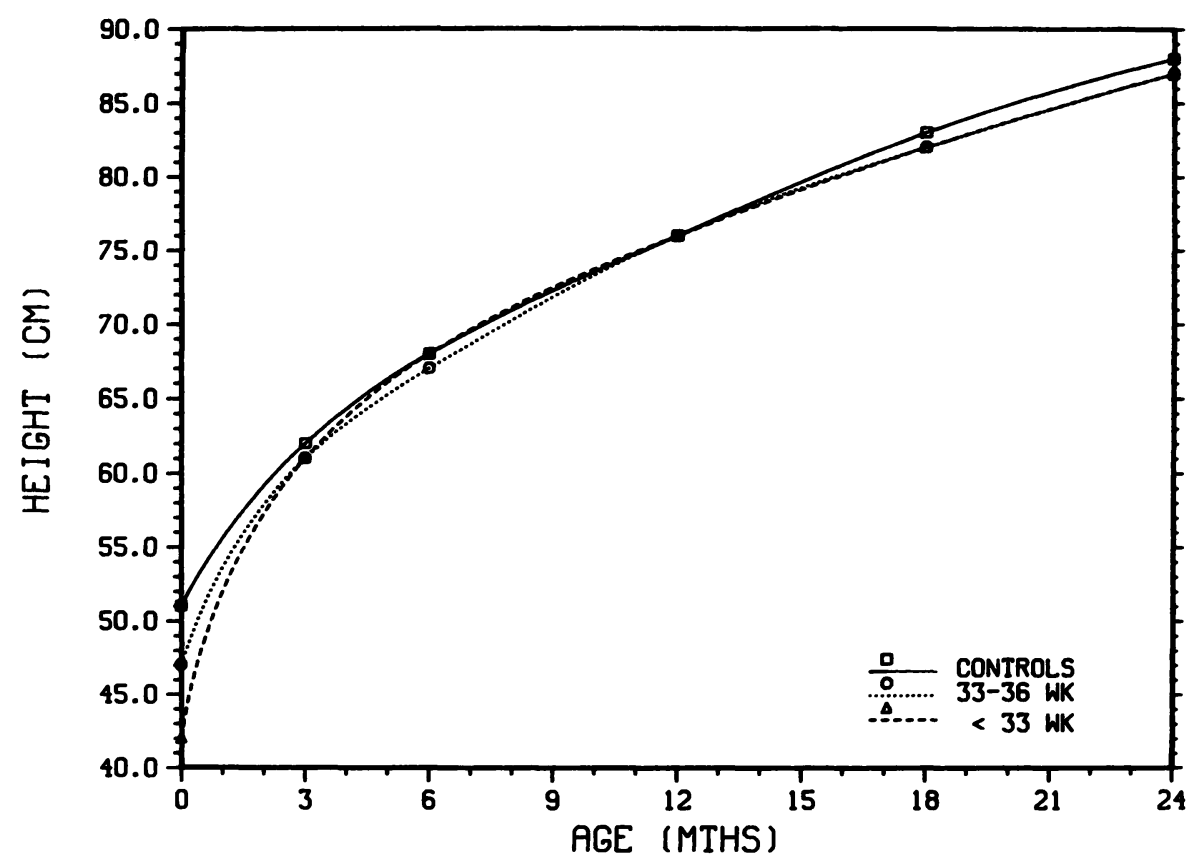

Figure 2. The median height curves of the preterm infants with 33-36 and $<33$ weeks gestational age and the control infants. 


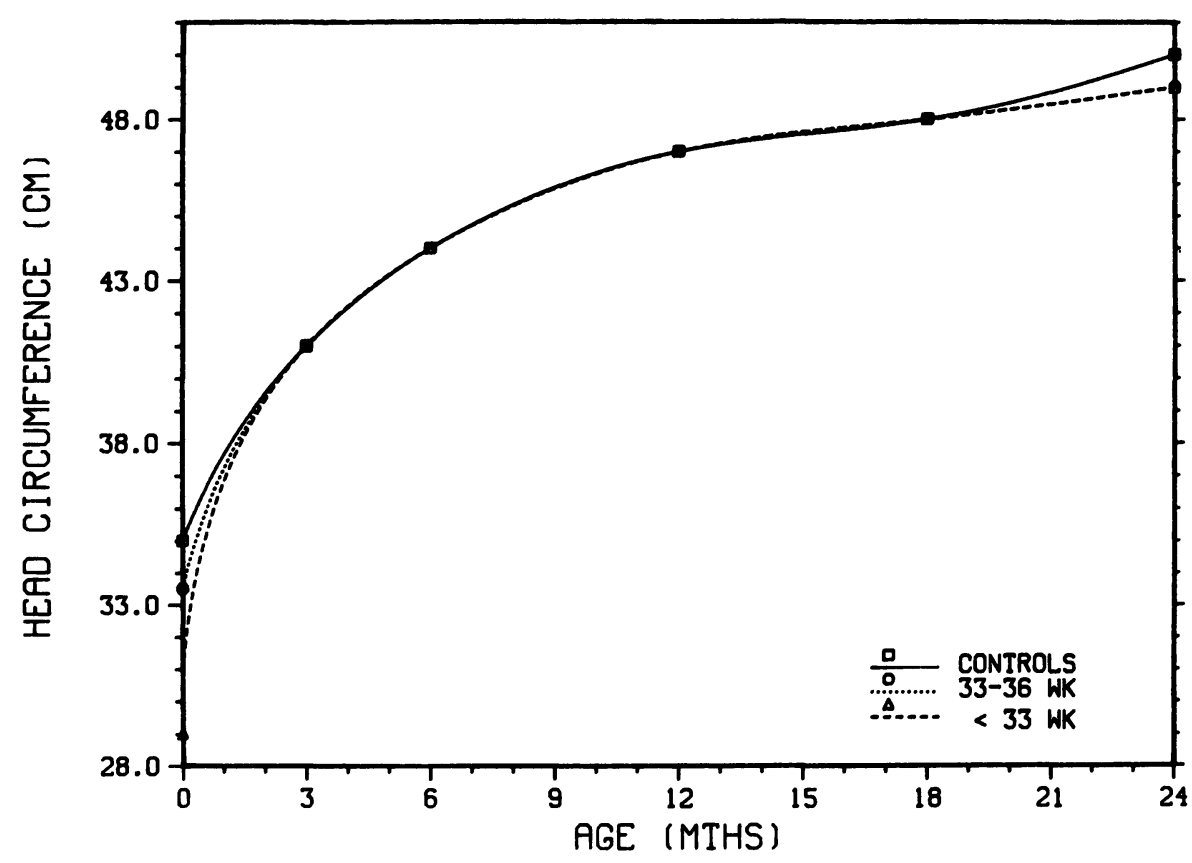

Figure 3. The median head circumference curves of the preterm infants with $33-36$ and $<33$ weeks gestational age and the control infants.

The pre-term SGA infants remained smaller than the pre-term AGA and the control infants in all measures throughout their first two years of life (figures 4-6). At two years of age the median weight of the preterm SGA infants remained 1.8 $\mathrm{kg}$, the median height $3 \mathrm{~cm}$ and the median head circumference $1 \mathrm{~cm}$ lower than those of the control infants (table II). In all measures the differences between the preterm SGA and AGA infants were significant $(\mathrm{p}<0.001)$.

The preterm infants with birth weights of $2000 \mathrm{~g}$ or more did not significantly differ in any measure from the control infants at two years of age, whereas the preterm infants with birth weights of less than $2000 \mathrm{~g}$ remained smaller than the control infants as well as the pre-term infants with birth weights of $2000 \mathrm{~g}$ or more in all measures (table II).

Moderate or severe RDS seemed to have no impact on the growth of those preterm infants who suffered from the disease. Significant differences between the preterm infants with no or mild RDS and the control infants were seen in all measures at two years of age (table II).

\section{Discussion}

In the present study the growth of most preterm infants was satisfactory. The small number of infants with very low gestational ages or birth weights may have contributed to this result, as such infants have been reported to remain lighter and shorter than term infants [7, 11, 14]. Forslund and Bjerre [8] reported no differences in weight and height between pre-term infants at 18 months of conceptional age and full-term control infants. The catch-up growth was seen by three months of conceptional age.

Fetal growth retardation clearly predicted later growth. The AGA preterm infants were comparable with their full-term peers in all measures at two years, whereas the SGA infants remained smaller than the controls in all measures despite the catch-up growth during the first months of life, as reported previously [9]. In Bjerre's [2] report concerning Swedish low birth weight children the SGA children were significantly shorter and their osseous maturation was less advanced than that of the AGA children regardless of gestational age or birth weight. 


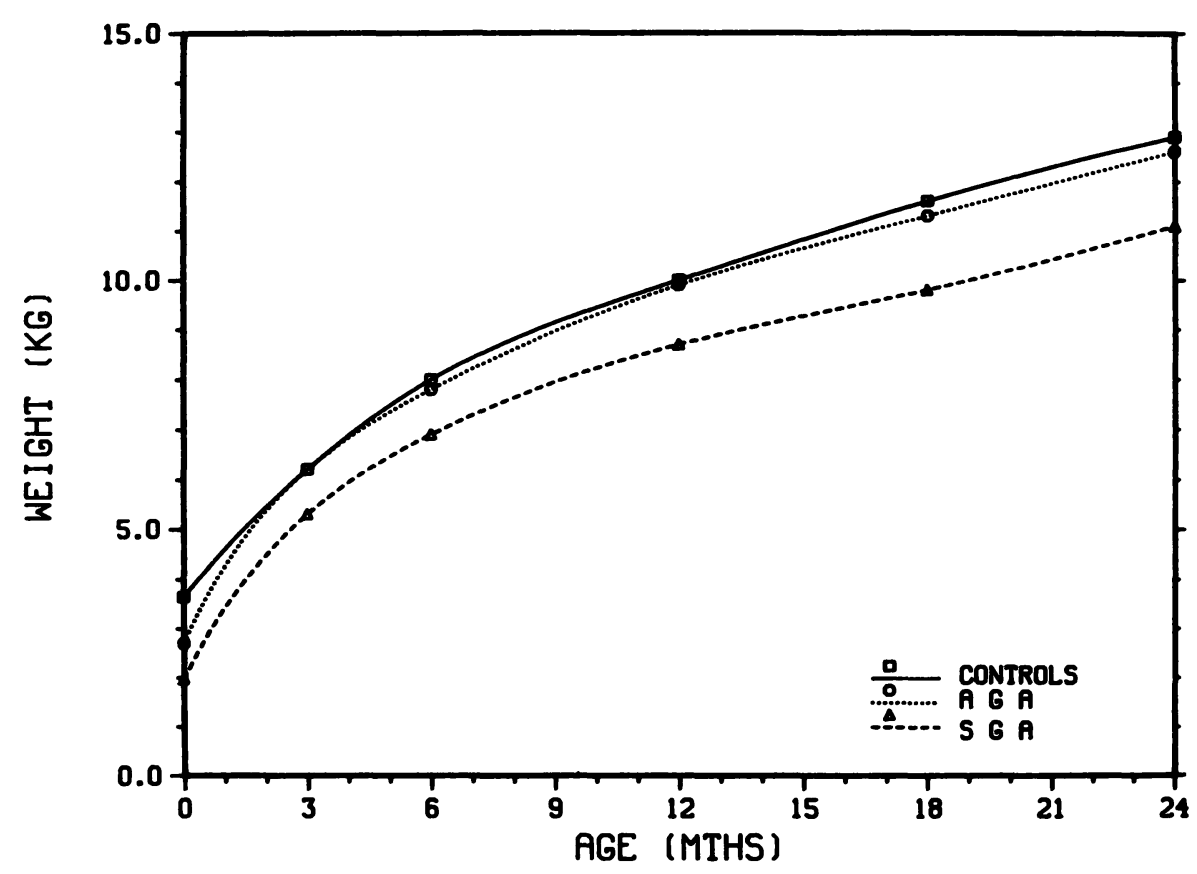

Figure 4. The median weight curves of the preterm appropriate-for-gestational-age (AGA), small-for-gestationalage (SGA) infants and the control infants.

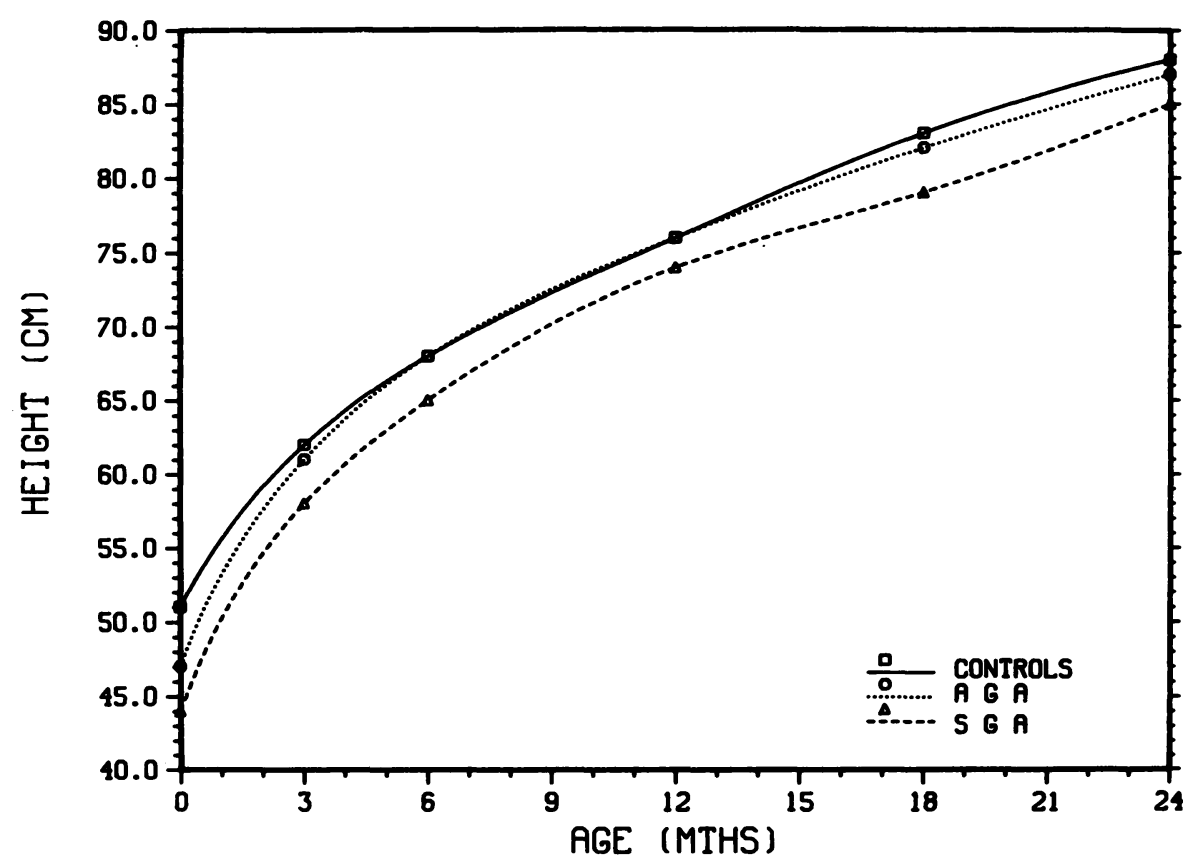

Figure 5. The median height curves of the preterm appropriate-for-gestational-age (AGA), small-for-gestationalage (SGA) infants and the control infants. 


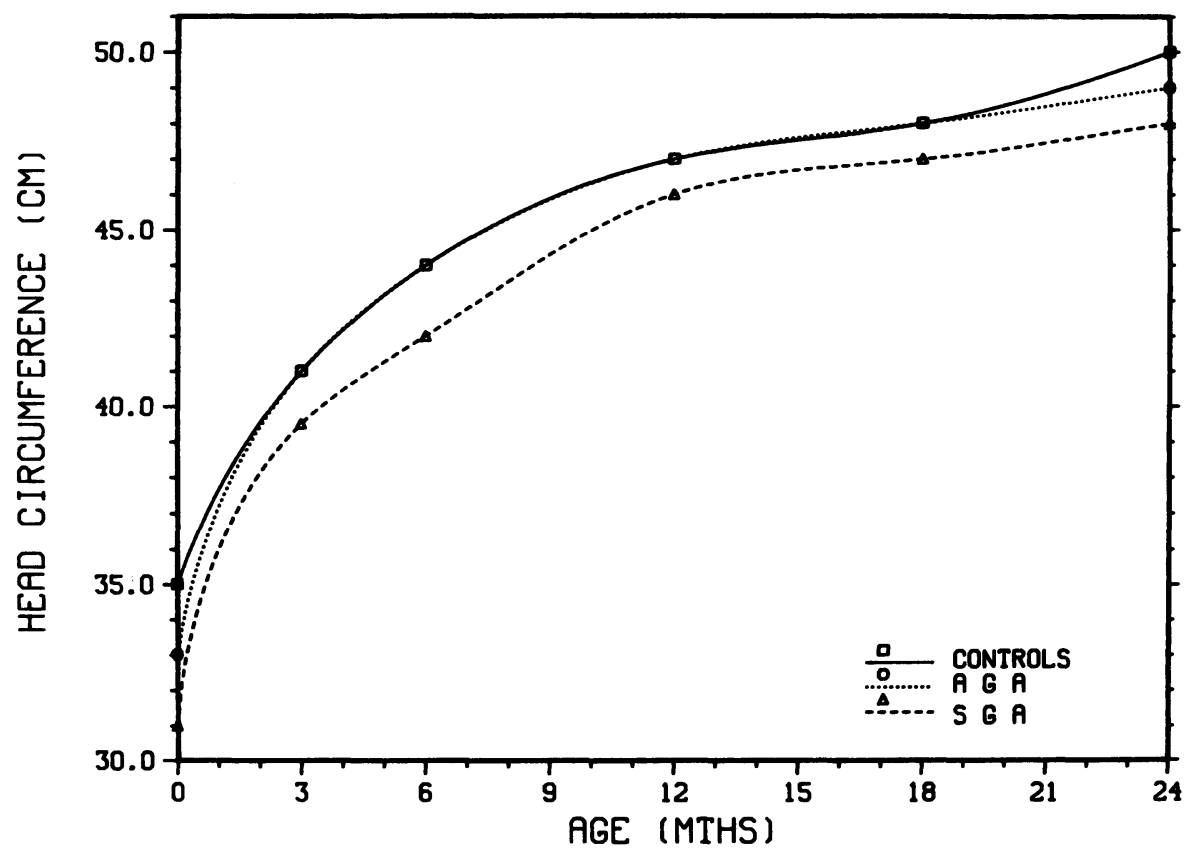

Figure 6. The median head circumference curves of the preterm appropriate-for-gestational-age (AGA), small-forgestational-age (SGA) infants and the control infants.

Table II. The median weights $(\mathrm{kg})$, heights $(\mathrm{cm})$ and head circumferences $(\mathrm{cm})$ with the 10th and 90th Percentiles at 24 months of age of the preterm and the control infants.

\begin{tabular}{|c|c|c|c|c|c|c|c|c|c|}
\hline \multirow[t]{2}{*}{ Measure } & \multicolumn{9}{|l|}{ Group } \\
\hline & $33-36 w$ & $<33 \mathrm{w}$ & AGA & SGA & $\geq 2000 \mathrm{~g}$ & $<2000 \mathrm{~g}$ & $\begin{array}{l}\text { RDS } 0 \\
\text { or } 1\end{array}$ & $\begin{array}{l}\text { RDS } 2 \\
\text { or } 3\end{array}$ & Control \\
\hline \multicolumn{10}{|l|}{ Weight } \\
\hline Median & 12.5 & 11.9 & 12.6 & 11.1 & 12.7 & 11.5 & 12.4 & 12.9 & 12.9 \\
\hline 10th & 11.0 & 9.7 & 11.0 & 9.9 & 11.1 & 9.7 & 10.8 & 10.7 & 11.2 \\
\hline \multirow[t]{3}{*}{ 90th } & 14.5 & 14.6 & 14.6 & 13.0 & 14.6 & 13.2 & 14.5 & 14.6 & 14.9 \\
\hline & $* *$ & $* *$ & $* * *$ & $* * *$ & & $* * *$ & $* * *$ & & \\
\hline \multirow{2}{*}{\multicolumn{10}{|c|}{ Height }} \\
\hline & & & & & & & & & \\
\hline Median & 87.0 & 87.0 & 87.0 & 85.0 & 87.0 & 84.0 & 87.0 & 88.0 & 88.0 \\
\hline 10th & 84.0 & 79.0 & 84.0 & 81.0 & 84.0 & 79.0 & 83.0 & 83.0 & 84.0 \\
\hline \multirow[t]{2}{*}{ 90th } & 92.0 & 91.0 & 92.0 & 87.0 & 92.0 & 89.0 & 91.0 & 92.0 & 92.0 \\
\hline & $* *$ & $*$ & $*$ & $* * *$ & & $* * *$ & $* * *$ & & \\
\hline \multicolumn{10}{|l|}{ Head } \\
\hline \multicolumn{10}{|l|}{ Circumf. } \\
\hline Median & 49.0 & 49.0 & 49.0 & 48.0 & 49.0 & 48.0 & 49.0 & 49.0 & 50.0 \\
\hline 10th & 47.0 & 47.0 & 47.0 & 46.0 & 47.0 & 46.0 & 47.0 & 48.0 & 48.0 \\
\hline \multirow[t]{3}{*}{ 90th } & 51.0 & 51.0 & 51.0 & 50.0 & 51.0 & 50.0 & 51.0 & 51.0 & 51.0 \\
\hline & $*$ & & & $* * *$ & & $* * *$ & $* *$ & & \\
\hline & & & & +++ & & +++ & & & \\
\hline
\end{tabular}

${ }^{*}=\mathrm{p}<0.05,{ }^{* *}=\mathrm{p}<0.01,{ }^{* * *}=\mathrm{p}<0.001 \quad$ compared with the controls

${ }^{+}=\mathrm{p}<0.05,{ }^{++}=\mathrm{p}<0.01,{ }^{+++}=\mathrm{p}<0.001$ compared between the preterm groups 
Studies on growth of infants with very low birth weights $[5,6,11,14]$ indicate that small premature infants free of severe disease regain their birth weights in 2-3 weeks and eventually grow at the same rate as infants born at term. In the present study the preterm infants with birth weights below 2000 grams did not reach in growth their peers with birth weights of 2000 grams or more or the term infants. The SGA preterm infants had birthweights mostly below 2000 grams. This probably predicts the outcome rather than the birth weight alone.

Moderate or severe RDS did not seem to have any effect on later growth. Most of the preterm SGA infants belonged to the 'no or mild RDS'group, which also explains the poorer growth of this group.

An AGA preterm infant free from neonatal disease is likely to reach normal weight, height, head and thorax circumference during early childhood. Birthweights rather than gestational age predicts postnatal growth. Fetal growth retardation may alter later growth potential, or genetic characteristics, malformation syndromes and eg. certain intrauterine infections may include diminished growth potential and thus predict both fetal and postnatal growth [1]. With advancing pre- and postnatal diagnostic facilities a fetus or newborn infant with growth retardation may be aetiologically defined and his/her growth prognosis as well as neurodevelopmental outcome more accurately estimated. Even though neurodevelopmental handicaps far more seriously impact the child's life than growth disturbance does, the growth of a child with short gestation or low birth weight should be carefully followed-up. If the infant or child presents with growth disturbance, its aetiology should be examined. Prematurity as such unlikely accounts for the condition.

\begin{abstract}
The somatic growth of a regional birth cohort of 351 preterm infants was followed during their first two years. The measurements of weight, height, head and thorax circumferences took place at the well-baby clinics run by public health nurses at 3,6,12,18 and 24 months of conceptional age. The growth of the preterm infants was compared with that of their term peers with uncomplicated course of pregnancy, labour, delivery and neonatal period. The preterm infants without intrauterine growth retardation caught up the term control infants by three
\end{abstract}

months of concenptional age. The preterm small-forgestational age infants remained smaller than the preterm appropriate-for-gestational age or the control infants in all measures throughout their first two years of life. Birth weight rather than gestational age predicted the growth outcome in preterm infants. Moderate or severe respiratory distress had no impact on the future growth of the infants in the present material. Prematurity as such does not seem to influence the growth of preterm infants.

Keywords: Birthweight, growth, preterm, respiratory distress syndrome, small-for-gestational age.

\section{Zusammenfassung}

Das somatische Wachstum bei 351 unselektierten Frühgeborenen einer regionalen Gruppe während der ersten beiden Lebensjahre

Von Frühgeborenen wird berichtet, daß sie neben neurologischen Störungen auch mehr als Reifgeborene zu Wachstumsstörungen neigen. Die vorliegende Studie untersucht das Wachstumsverhalten von Frühgeborenen in der frühen Kindheit. Das Untersuchungskollektiv faßte alle im Zeitraum eines Jahres in einer Region geborenen Kinder mit weniger als 37 vollendeten Schwangerschaftswochen zusammen. Als Kontrollgruppe dienten die im gleichen Jahr in derselben Region am Termin geborenen, gesunden Kinder. Insgesamt wurden $5356 \mathrm{Kinder}$ lebend geboren, davon waren 351 (6.6\%) Frühgeborene. Achtzehn Frühgeborene starben vor dem zweiten Lebensjahr und acht konnten in den Nachuntersuchungen nicht erfaßt werden. Somit waren die Daten von 325 Frühgeborenen im Alter von zwei Jahren verfügbar.
Die Nachuntersuchungen erfolgten in Kinderkliniken, die die Gesundheitsversorgung für Klein- und Vorschulkinder in Finnland leisten. Die Untersuchungen fanden 3, 6, 12, 18 und 24 Monate nach der Geburt statt. Gewicht, Größe und Kopfumfang wurden durch Personal der öffentlichen Gesundheitsdienste mit standardisierten Methoden gemessen. Bei den Analysen wurden nur die überlebenden Kinder berücksichtigt.

Die Frühgeborenen wurden entsprechend ihrem Gestationsalter $(<33$ Wochen, 33-36 Wochen), dem Geburtsgewicht ( $<2000 \mathrm{~g}, \geq 2000 \mathrm{~g})$, dem auf das Gestationsalter bezogene Gewicht (SGA, AGA) und dem Auftreten eines RDS (schwer, mittelgradig, gering oder kein RDS) in Untergruppen unterteilt. Zum statistischen Vergleich der Gruppen diente der Test nach MANN-WHITNEY mit der Korrektur nach BONFERRONI.

Frühgeborene mit einem Gestationsalter unter 33 Wochen, einem Geburtsgewicht unter $2000 \mathrm{~g}$ und Small-for- 
date-Frühgeborene (SGA) waren mit zwei Jahren signifikant untergewichtiger als die Kinder der Kontrollgruppe (Tabelle II). Klinisch am auffälligsten waren die SGA-Frühgeborenen. Im Alter von zwei Jahren lag ihr mittleres Gewicht $1.8 \mathrm{~kg}$ unter dem der Kontrollkinder. Sie hatten auch eine geringere Körperlänge und einen kleineren Kopfumfang. Darüberhinaus unterschieden sie sich in allen gemessenen Parametern von den Frühgeborenen mit adäquatem Geburtsgewicht (AGAGruppe). Kinder mit einem Geburtsgewicht unter $2000 \mathrm{~g}$ unterschieden sich signifikant von der Kontrollgruppe sowie von den Frühgeborenen mit einem Geburtsgewicht $\geq 2000 \mathrm{~g}$ hinsichtlich aller drei Meßgrößen. Ein mäßiges oder auch schweres RDS beeinflußte das Wachstum der Frühgeborenen nicht.

Das Wachstum von Frühgeborenen ohne weitere Komplikationen war zufriedenstellend. Lag eine intrauterine Wachstumsretardierung vor, waren die Kinder mit zwei Jahren deutlich untergewichtiger, kleiner und hatten einen geringeren Kopfumfang als die Reifgeborenen und die AGA-Frühgeborenen. Die meisten SGA-Kinder hat- ten ein Geburtsgewicht unter $2000 \mathrm{~g}$ und kein oder nur eine geringe RDS, was das Wachstum in diesen Gruppen beeinflußte. In der vorliegenden Studie hatte die Mehrzahl der Frühgeborenen ein Gestationsalter von $\geq 30$ Wochen. Andere Autoren berichten, daß extreme Frühgeborene kleiner bleiben als Reifegeborene [7, 11, 14]. Liegen jedoch keine anderen schwerwiegenden Erkrankungen vor, ist das Wachstumsverhalten normal $[5,6$, 11, 14]. Von SGA-Frühgeborenen berichten auch andere Autoren, daß ihr postnatales Wachstum beeinträchtigt ist.

Ein gesundes, nicht extremes Frühgeborenes mit einem für das Gestationsalter adäquaten Geburtsgewicht hat mit zwei Jahren ein normales Gewicht, eine normale Körpergröße und einen normalen Kopfumfang. Ein SGA-Frühgeborenes bleibt in allen Maßen hinter einem AGA-Kind oder Reifgeborenen zurück. Wenn ein AGAFrühgeborenes ohne Komplikationen bei der Geburt eine Wachstumsstörung aufweist, sollte man nicht die Prämaturität anschuldigen, sondern nach anderen Ursachen fahnden.

Schlüsselwörter: Geburtsgewicht, Prämaturität, RDS, Small-for-date-Kinder, Wachstum.

\section{Résumé}

Croissance somatique au cours des deux preimières années de vie d'une cohorte de naissances régionales comprenant 351 enfants prématures non selectionnés

A côté des troubles neurodéveloppementaux, les enfants prématurés sont considérés comme plus enclin à présenter des problèmes de croissance que les enfants à terme. Cette étude a été menée à bien pour explorer la croissance des prématurés au cours de la petite enfance. La population étudiée représente une cohorte régionale de naissances d'une année d'enfants de moins de 37 semaines gestationnnelles révolues. Les nouveaux-nés en bonne santé, à terme nés au cours de la même année, dans la même région ont servi de contrôles. 5356 enfants au total sont nés vivants, $6,6 \%$ étaient prématurés $(351$ cas). 18 prématurés sont morts avant l'âge de deux ans et 8 ont été perdus de vue. Le devenir à deux ans est connu pour 325 prématurés.

La surveillance s'effectue dans les centres d'enfants bien portants qui assurent les soins de santé primaire pour les petits enfants et les enfant en préscolaire en Finlande. Les examens ont lieu à $3,6,12,18$ et 24 mois d'âge conceptionnel. Les nurses de santé publique effectuent de façon standardisée les mesures du poids, de la taille et du périmètre céphalique. Seuls les survivants ont été inclus dans l'étude.

On a divisé les enfants prématurés en sous-groupes selon l'âge gestationnel ( $<33$ semaines, 33-36 semaines) selon le poids de naissance $(<2000 \mathrm{~g}, \geq 2000 \mathrm{~g})$, selon l'eutrophie ounon, selon le terme gestationnel (SGA, AGA) et selon le syndrome de détresse respiratoire (SDR) (sévère ou modéré, léger ou absent). Pour la comparaison entre groupes on a utilisé le test de MANNWHITNEY avec la correction de BONFERRONI.
Les enfants prématurés de moins de 33 semaines de poids de naissance de moins de $2000 \mathrm{~g}$ et qui était hypotrophes demeurent de façon significative d'un poids inférieur à celui des enfants contrôlés à terme (tableau II). Cliniquement, le groupe le plus important est représenté par le groupe des prématurés SGA dont le poids moyen à deux ans est inférieur à $1,8 \mathrm{Kg}$ à celui du groupe contrôle. Les prématurés SGA sont aussi plus petits et ont un périmètre cranien plus petit que les enfants témoins. Ils diffèrent également pour toutes les mesures des enfants prématurés AGA. Les enfants de poids de naissance inférieur à $2000 \mathrm{~g}$ sont significativement différents des enfants du groupe contrôle et des prématurés de poids de naissance supérieur ou égal à $2000 \mathrm{~g}$ pour toutes, les mesures (tableau II). Le SDR sévère en modéré n'exerce pas d'influence sur la croissance des prématurés.

La croissance des prématurés en l'absence de complications est satisfaisante. Les prématurés avec retard de croissance intra-utérin demeurent légèrement plus léger, plus court et ont une plus petite tete encore à 2 ans que les enfants à terme et que les prématurés AGA. Beaucoup d'enfants SGA ont un poids de naissance inférieur à $2000 \mathrm{~g}$ et n'ont pas de SDR ou seulement un SDR léger, ce poids influence l'évolution de la croissance dans ce groupe. La majorité des enfants prématurés de cette étude ont un âge gestationnel de 30 semaines ou plus. D'autres auteurs ont rapporté que les très grands prématurés demeurent plus petits que les enfants à terme $(7,11,14)$. Néanmoins chez ces enfants le taux de croussance est normal $[5,6,11,14]$ en l'absence de maladie grave. Les prématurés SGA ont été déçu par d'autres $[2,9]$ comme ayant une mauvaise croissance pas-natale. 
Un enfant modérément prématuré, en bonne santé, AGA atteindra un poids une taille et un périmètre cranien normal à deux ans. Un prématuré SGA demeurera plus petit pour toutes les mesures que son semblable pré- maturé AGA à à terme. Si un prématuré AGA en l'absence de complication présente un trouble de la croissance, on doit considérer qu'il existe d'autres raison que la prématurité.

Mots-clés: Croissance, hypotrophie, poids de naissance, prématuré, syndrome de détresse respiratoire.

\section{References}

[1] Allen MC: Developmental outcome and followup of the small for gestational age infant. Semin Perinatol 8 (1984) 123

[2] BJERRE I: Physical growth of 5-year-old children with low birth weight. Acta Paediatr Scand 64 (1975) 33

[3] Dixon WJ (ed): BMDP. Biomedical Computer Programs, P-Series. University of California Press, Berkeley (1983)

[4] Dubowitz L, V Dubowitz, C Goldberg: Clincal assessment of gestational age in the newborn infant. J Pediatr 77 (1970) 1

[5] Fisch RO, MK Bilek, LD Miller, PR Engel: Physical and mental status at 4 years of age of survivors of the respiratory distress syndrome. J Pediatr 84 (1975) 497

[6] FitzhaRdINGE PM: Early growth and development in low-birth-weight infants following treatment in an intensive care nursery. Pediatrics 56 (1975) 162

[7] Fitzhardinge PM, K Pape, M arstikaitis, M BOYLE, S ASHBY, A ROWLEY, C NETLEY, PR SWYER: Mechanical ventilation of infants of less than 1,501 gm birth weight: Health, growth and neurological sequelae. J Pediatr 88 (1976) 531

[8] ForsLund M, I BJERRE: Growth and development in preterm infants during the first 18 months. Early Hum Dev 10 (1985) 201

[9] HaCK M, IR Merkatz, SK MC Grath, PK Jones, AA FANAROFF: Catch-up growth in very-low-birth weight infants. Am J Dis Child 138 (1984) 370

[10] Health Services 1982. Yearbook of the National Board of Health in Finland 1981 -1982, SVT XI, 78, Valtion Painatuskeskus, Helsinki 1984
[11] Pape KE, RJ Buncic, S Ashby, PM Fitzhardinge: The status at two years of low-birth-weight infants born in 1974 with birth weights of less than 1,001 gm. J Pediatr 92 (1978) 253

[12] ParkIN JM, EN HeY, JS Clowes: Rapid assessment of gestational age at birth. Arch Dis Child 51 (1976) 259

[13] Pifkkala P, P Kero, R Erkkola, M SillanpäÄ: Perinatal events and neonatal morbidity: an analysis of 5380 cases. Early Hum Dev 13 (1986) 249

[14] Teberg AJ, Pyk WU, Je Hodgman, C Mich, J GARFINKLE, S AZEN, WA WingerT: Infants with birth weight under $1500 \mathrm{~g}$ : Physical, neurological and developmental outcome. Crit Care Med 10 (1982) 10

[15] VÄLIMÄKI I, P Kero, H Korvenranta, H Ekblad: New trends in monitoring of artificially ventilated neonates. In: Vignali M, EV COSMI, M LUERTI: Diagnosis and treatment of fetal lung immaturity. Masson Italia Editori, Milan 1986

[16] VÄLIMÄKI IAT, H KoRvenRanta, PO Kero: Monitoring of an infant with RDS. In: RAIVIO KO, N Hallman, K KouvalaInen, I VälimäkI: Respiratory distress syndrome. Academic Press, London 1984

Received May 31, 1988. Accepted August 22, 1988.

Paula Piekkala, M.D.

Department of Public Health

University of Turku

Lemminkäisenkatu 1

SF-20520 Turku, Finland 